Max-Planck-Institut für demografische Forschung

Max Planck Institute for Demographic Research

Konrad-Zuse-Strasse $1 \cdot$ D-18057 Rostock · GERMANY

Tel +49 (0) 3812081 - 0; Fax +49 (0) 3812081 - 202;

http://www.demogr.mpg.de

MPIDR WORKING PAPER WP 2006-048

NOVEMBER 2006 (REVISED OCTOBER 2007)

\title{
Fertility and women's employment: a meta-analysis
}

Anna Matysiak (amatys@sgh.waw.pl)

Daniele Vignoli (vignoli@ds.unifi.it)

This working paper has been approved for release by: Gerda Ruth Neyer (neyer@demogr.mpg.de)

Deputy Head of the Laboratory of Contemporary European Fertility and Family Dynamics.

(C) Copyright is held by the authors.

Working papers of the Max Planck Institute for Demographic Research receive only limited review. Views or opinions expressed in working papers are attributable to the authors and do not necessarily reflect those of the Institute. 


\title{
Fertility and Women's Employment: a Meta-Analysis
}

\author{
Anna Matysiak $^{(1)}$ - Daniele Vignoli (2), * \\ ${ }^{(1)}$ Institute of Statistics and Demography, Warsaw School of Economics, Warsaw (Poland) \& Gdansk Institute for \\ Market Economics, Warsaw Branch (Poland) \& Max Planck Institute for Demographic Research, Rostock (Germany) \\ (2) Department of Demography, University of Rome "La Sapienza”, Rome (Italy) \& Max Planck Institute for \\ Demographic Research, Rostock (Germany)
}

\begin{abstract}
Our research objective was to systematise the existing literature on the relation between fertility and women's employment at the micro-level. Instead of carrying out a traditional literature review, we conducted a meta-analysis. This allowed us to compare estimates from different studies standardised for the country analysed, the method applied, control variables used, or sample selected. We focused on two effects: the impact of work on fertility and the impact of young children on employment entry. First, we found a high variation in the studied effects among the institutional settings, reflecting the existence of a north-south gradient. Second, we observed a significant change in the effects over time. Finally, we demonstrated that a failure to account for the respondent's social background, partner and job characteristics tends to produce a bias to the estimated effects.
\end{abstract}

Keywords: Fertility, Women's Employment, Meta-Analysis, Welfare Regimes

\footnotetext{
${ }^{*}$ The authors share the general line of the paper. The names are listed in alphabetical order.
} 


\section{Introduction}

Since recent decades, period total fertility has been decreasing in almost all industrialised countries, reaching values well below the replacement level. It has often been argued that an increase in women's labour-force participation has largely contributed to the change in reproductive behaviour. Since the mid-1980s, however, the European countries with the highest women's labour-force participation have been showing the highest fertility, too, and vice versa. This phenomenon is explained by different levels of incompatibility between work and motherhood across countries, depending on their legal and cultural frameworks. In this context, the question emerges whether women's employment and fertility are indeed correlated or whether the observed correlation is a spurious one, caused by common antecedents of the two variables (Weller 1977). Some studies investigating the correlation between women's employment and childbearing at the macro-level provide evidence for the latter (e.g. Engelhardt et.al., 2004; Apps and Rees 2004). Evidence at the micro-level, however, is fragmented and often provides contradictory results. A lack of systematisation makes it difficult, if not impossible, to draw general conclusions on the size and direction of the effect under investigation.

The objective of this paper was to systematise the existing literature on the relation between women's employment and fertility at the micro-level. Instead of conducting a narrative literature review, we applied meta-analytic techniques. A standard literature review usually consists of commentary findings of previous works. The character of this approach, however, is a qualitative one. It neither allows for a quantitative assessment of the effect of interest nor does it enables its standardisation for different methods applied across studies. The inability to compare estimates obtained by different researchers often leads to a substantial bias in the selection of the literature used in the review. These problems can be overcome by applying a meta-analysis, in other words, by conducting a quantitative literature review. This methodology, relatively new in the social sciences, has been developed in order to synthesise, combine, and interpret the abundance of empirical evidence on a certain topic. It offers a clear and systematic way to compare the results of different studies standardised for the country, the method applied, the control variables employed, and the sample selected, etc.

Our study focuses on two effects: the impact of women's employment on childbearing and the effect of young children on mothers' entry into employment. We conducted an overview of all research works available concerning Europe, the US, Canada, and Australia. When discussing the results, we focus on the differences in the studied effects across various institutional settings.

The paper consists of seven sections, including the introduction. Section 2 constitutes an introduction to the discussion on the association between women's work and fertility. Section 3 briefly discusses the method of meta-analysis. Section 4 presents the criteria for the selection of the studies and Section 5 provides information on meta-analytic techniques applied in this paper. The results are presented in Section 6, followed by Section 7, which summarises and discusses the findings. 


\section{Theoretical framework: on the changing correlation between fertility and women's work}

In the 1980s, many researchers still associated the severe drop in fertility experienced by all industrialised countries in the last 40 years with a rise in women's labour-force participation. For example, the authors of the concept of the second demographic transition ascribe the fall in the propensity to have children to the rising economic autonomy of women and their strive for selffulfilment, among other things (Van de Kaa 1987, 1988; Lesthaeghe 1991, 1992). Similarly, referring to the high opportunity costs of motherhood, particularly for highly-skilled women, Becker sees the reasons for the falling propensity to have children in the rise of women's educational and labour-market attachment (Becker 1993).

However, since the mid 1980s the trends observed at the macro-level seem to contradict these theories. The countries with the highest women's labour-force participation have become characterised by highest rather than lowest fertility. Moreover, in the mid 1980s, the downward trend in fertility reversed in this group of countries. These observations have led to discussions on the changing correlation between women's labour-force participation (FLFP) and total fertility at the macro-level. Castles (2003), Rindfuss et.al. (2003), and Brewster and Rindfuss (2000) attribute the reversal to the correlation sign in the weakening incompatibility between childrearing and females' employment in some countries, resulting from changes in the institutional context (e.g. changing attitudes towards working mothers, the introduction of family and labour-market policies aimed at the reconciliation between work and family). Furthermore, Ahn and Mira (2002) underline the role of cross-country differences in the income effects of women's wages, unemployment and labour-market rigidities in terms of fixed working hours. The existence of a positive cross-country correlation in Western European countries since the 1990s is confirmed by Del Boca et. al. (2003), whereas Muszyńska (2007) provides evidence that a low intensity of cultural and structural conflict between family and work coexists with high fertility and high women's employment. Other studies, however, show that the correlation between the total fertility and FLFP remains negative if one takes into account cross-country heterogeneity in the magnitude of this association (Kögel 2004, 2006). Still, the findings by Kögel $(2004,2006)$, point to a weakening in this negative relationship. Apart from the direction and sign of the correlation between women's labour-force participation and fertility, some studies addressed the causal character of this relationship. Applying vector correction models on time-series data from six developed OECD countries, Engelhardt et.al. (2004) show that total fertility and FLFP are causally related in both directions. The authors presume the finding to suggest that the simultaneous movements of total fertility and FLFP are caused by common exogenous third variables, such as social norms, social institutions, financial incentives, or the availability and acceptability of contraception. This result is consistent with the theoretical model by Apps and Rees (2004), who show that greater availability of childcare and a system of individual rather than joint taxation have a positive effect on total fertility as well as the FLFP, producing a positive correlation between the two variables.

The studies mentioned above provide evidence on the association between women's employment and fertility at the macro-level. Yet, from the perspective of formulating policy recommendations, an investigation of the interdependencies between the two variables at the microlevel is needed. The evidence provided by the literature on this matter is very wide. Although it 
generally suggests that both variables are negatively correlated, there are exceptions to this rule. An insignificant influence of women's employment on the transition to childbirth was found for many countries, beginning with Sweden (Berinde 1999; Santow 2001), and ending at Italy (Bernardi and Nanio 2005). The evidence of a positive effect of women's employment on birth risks found for East Germany (Kreyenfeld 2004) and Hungary (Róbert and Bukodi 2005) is even more striking. Similarly, studies on entry into employment report an insignificant effect of young children on fulltime employment (Drobnič 2000 for lonely mothers in the US; Giannelli 1996 for West Germany; Leth-Sorensen and Rohwer 2001 for Denmark), part-time employment (Drobnič et.al. 1999 and Drobnič and Wittig 1997 for the US; Drobnič 2000 for West Germany) or employment in general (Corijn 2001 for Flanders; Felmlee 1993 for the US; Bernardi 2001 for Italy). Moreover, empirical evidence for the US (Hofmeister 2006, Grunow et.al. 2006) and Denmark (Grunow and LethSørensen 2006) even suggests that mothers of young children are more likely than other women to enter employment.

As this short narrative literature overview has shown, the empirical evidence on the issue is very wide. Nevertheless, for several reasons it is difficult, if not impossible, to draw conclusions from it. First, in spite of the fact that the majority of the studies indicate a negative association between fertility and women's employment, many present contradictory results. Second, the methods employed to compute the effects under investigation largely vary. Third, even if the methods are similar in nature, different control variables often are included into the model, possibly influencing the size of the studied effect. Moreover, the age of the children studied is categorised differently across studies and this makes it impossible to compare the strength of the effect. Finally, the sample under study is often selected according to the research objectives of the author. Therefore, in order to draw conclusions on the association between women's employment and fertility at the micro-level, a quantitative systematisation of the existing studies is required. A metaanalysis seems to provide a solution.

\section{Meta-analysis as a quantitative literature overview}

Within the framework of experimental research, meta-analysis has been employed increasingly in the social sciences (Vemer et al. 1989; Waldorf and Byrun 2005; Weichselbaumer and WinterEbmer 2005; Amato and Keith 1991; Wagner and Wei $\beta$ 2006). It is designed to deal with a large amount of empirical studies, often providing contradictory results.

In order to conduct a meta-analysis, papers researching a topic of interest are collected in a systematic manner. First, estimated coefficients are selected across studies and recalculated in a standardised way into comparable indicators (i.e. effect sizes). The indicators reflect the magnitude of the association in each study. Next, they are combined into single summary indicators. If the computed effects contain a large amount of heterogeneity, regression techniques should be applied. Within this analytical framework, the dependent variable denotes the effect sizes and all methodological features of a particular study can be used as control variables.

Meta-analysis has several advantages to a standard literature review (see e.g. Stanley 2001). The first is its quantitative character. While standard narrative literature review consists of 
commentary findings of various works, meta-analysis allows for a quantitative assessment of the effect of interest. Second, it provides a researcher with the opportunity to standardise the studied effects for the country looked at, the method of analysis applied, the control variables employed, and the sample selected, etc. Not only does it help to explain the wide variation in research findings across these studies, but it also enables the evaluation of the merits of different research methods, designs, data, and country-specific contexts. Third, it allows the inclusion of all papers available worldwide, meeting a priori defined criteria. This leaves no room to the reviewer for a subjective assessment of the studies and allows avoiding a substantial selection bias. The reliability and quality of the papers is later tested within the meta-regression framework.

Meta-analysis has limitations, however. First, it is much more confined in its range than a traditional literature review, which can cover a very broad range of studies (i.e. without an a priori defined criteria) and even include studies that are only marginally related to the phenomenon under investigation. Second, since publishers tend to accept studies that report significant results, it may be even impossible for the meta-analyst to locate a number of relevant studies on the topic (the socalled "file-drawer" problem). Note, however, that many ways have been developed in the methodological literature to test and deal with this problem (Rosenthal1979; Card and Krueger 1995; Begg and Mazumdar 1994). Finally, a common problem is that researchers often do not report results required for conducting a meta-analysis (i.e. standard errors or t-statistics). It thus is necessary to make assumptions in order to overcome the lack of information.

\section{Selection of studies}

In order to carry out a meta-analysis, a necessary preliminary step consists of constructing one's own meta-data. The principle of completeness drives the choice of the original papers. Our article's search strategy, following Stuck et al. (1999), consisted of three stages: first we used Current Contents and EconLit, universal research databases ${ }^{\dagger}$; second, we checked the references in existing articles; third, we asked experts for their recommendations. Due to the fact that the Current Contents covers articles published in the time-span 1990-2006, all selected studies were limited to this publication period.

The search was performed in the seven months from April 2006 to October 2006. In order to collect a representative sample of high quality studies, we merely focused on reviewed articles and chapters in books and monographs, leaving out working papers and internal research reports. Our systematic search was conducted using a specific combination of selected general keywords (work, fertility, childbearing, transition, progression, labour market, employment, etc). We ended the search at saturation point - in other words when, combining the different keywords and adding new ones, we obtained articles already selected. Applying the systematic search strategy, we found

$\dagger$ Current Contents and EconLit, provided by the surface OVID, give access to complete bibliographic information and table of contents of over 7,600 of the world's leading scholarly journals and to more than 2,000 book series covering all disciplines. They cover items published since the year 1990. 
around 150 potential articles on the two effects studied, namely the effect of women's work on childbearing and the effect of young children on females' transition to employment.

We limited our study selection to works that clearly explored the women's transition to birth and to employment. Amongst them, only the studies that provide sufficient information to asses a causal relationship between work and fertility were included. Thus, we restricted the search to longitudinal studies.

Furthermore, we decided to exclude papers where the transition to employment after childbirth was analysed; the reason being that in these papers the age of the child is the process time and the calculated baseline intensities, even if reported, do not measure the effect which we focus on in our study, i.e. effect of young children versus older ones or no children on women's employment entry.

English, German, Italian, and Polish-language articles were considered. We are quite positive of having a representative sample of existing studies, possibly with a bias towards an English-language literature. Omission of the studies published in other languages may cause an under-representation of some countries in our analysis. This is a common problem in the literature reviews. On the other hand, however, we did not locate many of them in the literature sources we used.

At the end of the selection process, we came up with 30 papers on the transition to childbirth and 29 papers on employment entry. Some authors presented an analysis of more than one independent sample or studied more than one transition in the same paper. These estimates were treated as independent and were all included into our analysis. We accepted the estimates from final models only. When the same author published two papers using the same dataset and the same model specification, an average estimate was calculated based on the reported outcomes. However, when the same dataset was used, but a different model was estimated, we included both estimates in order to avoid the possibility of a study selection bias.

Overall, the search procedure gave us a total of 90 effects of employment on fertility and 60 effects of young children on entry into employment (for details, see Tables 1a and 1b; for the list of all selected articles, see Appendix 1). The collected studies, apart from one, treat fertility as exogenous to employment or employment as exogenous to fertility. This is the most common way of investigating the relationship between the two variables in the literature. The studies that consider the endogeneity of these two variables are rare and most often based on instrumental variable methodology. Fertility is for instance instrumented with twin-births or contraceptive use which makes the studies too different to include them into our analysis.

After having collected the articles, we proceeded with the construction of two separate datasets: one for the transition to childbearing and another one for the transition to work. Data entry was conducted independently by each author for one of the two datasets. The reliability of each dataset was verified in the next step by the second author. 
Table 1a. Meta-sample: Transition to employment

\begin{tabular}{|c|c|c|c|}
\hline Type of transition & & $\begin{array}{l}\text { Number of } \\
\text { estimates }\end{array}$ & Countries \\
\hline from: & into: & & \\
\hline unemployment & & 3 & France, Finland, Denmark \\
\hline inactivity & employment & 9 & $\begin{array}{l}\text { Poland, Italy, Hungary, France, Denmark, West } \\
\text { Germany, Finland }\end{array}$ \\
\hline non-employment & & 21 & $\begin{array}{l}\text { The US, the UK, the Netherlands, Switzerland, } \\
\text { Spain, West Germany, East Germany }\end{array}$ \\
\hline unemployment & & - & - \\
\hline inactivity & $\begin{array}{l}\text { full-time } \\
\text { employment }\end{array}$ & 3 & Denmark, the UK, West Germany \\
\hline non-employment & & 14 & The Netherlands, West Germany, the US \\
\hline unemployment & & - & - \\
\hline inactivity & $\begin{array}{l}\text { part-time } \\
\text { employment }\end{array}$ & 1 & West Germany \\
\hline non-employment & & 9 & West Germany, the US \\
\hline
\end{tabular}

NOTE: Non-employment is defined as unemployment as well as inactivity.

Table 1b Meta-sample: Transition to childbirth

\begin{tabular}{|c|c|c|}
\hline Type of transition & $\begin{array}{l}\text { Number of } \\
\text { estimates }\end{array}$ & Countries \\
\hline First parity & 53 & $\begin{array}{l}\text { Flanders, France, the Netherlands, West Germany, the UK, } \\
\text { Italy, Spain, East Germany, socialist Hungary, post-socialist } \\
\text { Hungary, the socialist Czech Republic, the post-socialist } \\
\text { Czech Republic, socialist Poland, Norway, Sweden, Finland. }\end{array}$ \\
\hline Second parity & 17 & $\begin{array}{l}\text { France, Italy, Spain, socialist Poland, socialist Hungary, } \\
\text { Finland, Sweden }\end{array}$ \\
\hline Third parity & 18 & $\begin{array}{l}\text { France, Italy, Spain, socialist Hungary, Finland, Norway, } \\
\text { Sweden }\end{array}$ \\
\hline $\begin{array}{l}\text { Joint transition to first and } \\
\text { higher parities }\end{array}$ & 2 & The US, the UK \\
\hline
\end{tabular}

\section{Meta-analytic techniques}

\subsection{Calculation of effect sizes}

Our effect sizes are the $\log$ odds ratios, the log relative risks and the estimates of the OLS regressions weighted by the inverse of their variances. They come from the models, where the dependant variable is defined as the hazard of employment (full-time, part-time or employment in general), the hazard of birth (first, second, third, all birth orders together) or, in the case of the fixed-effects OLS regressions, deviation from the person-specific mean. The variance of the effect size is defined as a sum of the squared standard error and the between-study variation.

In order to study the influence of women's employment on childbearing, we selected the estimates of being employed or, if this was not possible, being employed full-time versus being 
inactive, unemployed or non-employed ${ }^{\ddagger}$. This was the most standard way of reporting the influence of work on childbearing. Sometimes, however, the original reference category was different from inactivity, unemployment, or non-employment. The coefficients then were recalculated according to the standard statistical procedures.

Our analysis of the effects of fertility on women's employment focused on children aged 06. This was the most frequent age interval, in which the age of the children was classified. Many authors, however, used other age intervals. In order to maintain coherence across studies, we fitted spline functions to all coefficients that refer to the influence of the age of children on women's entry into employment for each study. The size of the coefficient was the Y-axis value. We placed the mid-points of the reported age intervals on the horizontal axis. Given the parameters of the spline function, we were able to calculate the coefficient for the mid-point of the required age interval. Another problem we encountered while calculating the effects of children on women's employment is the different reference categories employed by researchers. The majority of authors defined the reference category as "having no children", but some used "having no children younger than" a certain age. We accepted both types of papers, but in the case of the latter we did so only if the age limit was at least seven. As a result we dropped three studies. Finally, the variable describing the age of the child was defined differently across the studies. The most frequent solution was to analyse the effect of the age of the youngest child. However, in some cases older children were categorised together with the youngest child (having children in the given age interval). Moreover, while in the two cases presented above the covariate describing the age of the child was defined as categorical, there were also papers where it was coded as continuous (number of children in a given age interval). We accepted these three solutions. The effect sizes were later standardised for the definition of the age of child and the type of reference category in the meta-regression framework.

The last problem we encountered while calculating the effect sizes was the lack of standard errors or other statistics allowing a direct calculation of standard errors (e.g. t-statistics or at least pvalues). This applied to the papers on transition to childbirth. Following the literature on metaanalysis, we made following assumptions. When the result was marked to be significant and no other details were available, we set the p-value equal to 0.05 . When the result was not significant and the upper limit for significance assumed by the author was 0.1 , we set the p-value at 0.45 , and when the upper limit was 0.05 , we used a p-value equal to 0.475 . When the significance was marked with stars only, we assumed the p-value to be equal to the mid-point of its interval.

\subsection{Testing for homogeneity}

The estimated effect sizes were tested for homogeneity, using the homogeneity test proposed by Hedges and Olkin (1985). The test statistic Q measures the extent to which individual effect sizes vary around the mean effect size. Significant values of $Q$ require an application of further procedures.

We expected large variation in the estimated effect sizes. The source of the variation lies in the differences in the institutional context, in which the employment and fertility decisions are

\footnotetext{
\$Non-employment is defined as unemployment as well as inactivity.
} 
taken, as well as in the peculiarities of the original studies in terms of the methods applied, the data looked at, sample restrictions, the types of the transition studied, the definitions of the reference category of the investigated coefficient, or any other variations in the effect measurements (see Section 5.1) Significant heterogeneity in the mean effect sizes was tackled with by estimating metaregressions.

\subsection{Meta-regression}

Our meta-regressions take the following form:

$Y_{j}=\sum \alpha w_{j}+\sum \beta c_{j}+\sum \vartheta v_{j}+\sum \theta s_{j}+\sum \delta m_{j}+\sum \gamma x_{j}+\xi_{j}, \quad j=1,2, \ldots, n$,

where $Y_{j}$ is the effect size of study $j, w_{j}$ are a set of dummies for the welfare regime, and $c_{j}$ for the cohorts covered, $\mathrm{v}_{\mathrm{j}}$ represent the control variables for the type of the transition and measurement of the studied effect (e.g. birth order, type of employment, type of non-employment, definition of the reference category, definition of the child's age variable, etc.), $s_{j}$ stand for dummies controlling for the sample selection (taking value 1 if the sample was restricted only to the ever-working, or married, or lonely mothers, or mothers of at least one child, or if it covered other ethnic groups apart from the nationals), $\mathrm{m}_{\mathrm{j}}$ denote variables standardising for the method and type of the data, and $\mathrm{x}_{\mathrm{j}}$ are implemented to standardise for the covariates incorporated as controls in the original studies. The parameters $\alpha, \beta, \vartheta, \theta, \delta, \gamma$ were estimated stepwise, using the standard maximum likelihood First, we introduced welfare regime and cohort variables into the model. They were followed by controls for the type of transition, the definition of the variable on the child's age, the type of the reference category, the sample selected, the method applied, and the type of the data and the control variables employed in the original studies.

The robustness of the meta-regression estimates was verified by conducting a sensitivity analysis. Namely, we estimated the same models on the samples reduced randomly by $10 \%$. Minor differences in the estimates prove that the outcomes are reliable.

\section{Empirical findings}

This section presents the results of the meta-analysis carried out. We first conducted a descriptive analysis of the mean effect sizes. However, due to the large variation between the studies investigated, we analysed next the effect sizes using the meta-regression. This allowed us to revise the impact of various factors on the magnitude of the investigated effects more carefully. In particular, we were able to study the variation in the effect sizes across different institutional settings after having eliminated the contaminating effects of different approaches.

In order to investigate the differences in the effect sizes with respect to the institutional context, we applied the Esping-Andersen classification of welfare regimes (Esping-Andersen 1999). As we included the Eastern European countries into our analysis, we added two new clusters: 
socialist, when the original analysis refers to the period before the breakdown of the communist regime, and post-socialist in the opposite case. We included East Germany into the latter cluster. Although the country adopted the West German legal framework following the fall of the Berlin Wall, the attitudes towards working mothers, the experience of socialism, and financial incentives for women to take up work largely differ in both parts of Germany (Matysiak and Steinmetz 2006). We succeeded in covering all welfare regimes in the analysis of the effect of women's employment on childbearing. Unfortunately, due to an insufficient number of available studies on the effect of young children on mothers' employment entry in the socialist, post-socialist, and familialistic welfare regimes we decided to concentrate only on the three remaining welfare regimes: conservative, liberal, and social-democratic ones. Thus, the number of studies included in our analysis on the effect of young children on women's employment entry decreased to 55. Table 2 below presents the resulting classification of the countries used in both analyses.

Table 2 The classification of the countries under study, based on the Esping-Andersen welfare regime typology

\begin{tabular}{lll}
\hline & $\begin{array}{l}\text { Effect of children aged 0-6 } \\
\text { on women's employment }\end{array}$ & $\begin{array}{l}\text { Effect of women's employment } \\
\text { on childbearing }\end{array}$ \\
\hline Conservative & $\begin{array}{l}\text { France (2), the Netherlands (12), } \\
\text { Switzerland (1), West Germany } \\
(16)\end{array}$ & $\begin{array}{l}\text { Flanders (2), France (7), the } \\
\text { Netherlands (2), West Germany } \\
(5)\end{array}$ \\
\hline Familialistic & - & Italy (9), Spain (6) \\
\hline Liberal & The UK (3), the US (16) & The UK (3), the US (3) \\
\hline Post-socialist & - & $\begin{array}{l}\text { Czech Republic (1), East } \\
\text { Germany (4), Hungary (1) }\end{array}$ \\
\hline Socialist & - & $\begin{array}{l}\text { Czech Republic (1), Hungary } \\
(11), \text { Poland (5) }\end{array}$ \\
\hline Social-democratic & Denmark (3), Finland (2) & $\begin{array}{l}\text { Finland (8), Norway (6), Sweden } \\
(16)\end{array}$ \\
\hline
\end{tabular}

NOTE: Number of effect sizes in parentheses.

\subsection{Univariate analysis}

Table 3 presents the mean effect sizes respectively of children aged 0-6 on mothers' employment entry and women's work on the birth risk calculated, based on the information in all collected studies.

Generally, one can see that the effect of children aged 0-6 on mothers' entry into employment is negative $(-0.29)$ and strongly significant $(p=0.000)$, whereas the effect of women's employment on childbearing is zero $(\mathrm{p}=0.9)$. However, as the homogeneity statistics developed by Hedges and Olkin indicate, these results contain a large amount of variation. This is consistent with our expectations. Specifically, one of the most important sources of heterogeneity can be the institutional context, in which employment and childbearing decisions are taken. For this reason, we disaggregated the mean effect size by the welfare regimes. 
The results show that the effect of young children on mothers' employment entry is on average significantly negative in conservative as well as liberal welfare regimes. Furthermore, the negative effect of young children on females' employment entry turns out to be much stronger in the conservative welfare regime than in the liberal showing higher conflict between work and family under this institutional setting. The social-democratic welfare regime forms an exception, with the mean effect of young children on mothers' employment entry insignificantly different from zero.

The mean effect sizes of women's employment on childbearing present almost the same picture. They are significantly negative in the liberal, conservative, and familialistic welfare regimes. In the social-democratic and socialist welfare regimes, the influence of females' employment on childbearing is on average insignificantly different from zero, whereas in the postsocialist welfare regime a significantly positive effect is found.

Table 3 - Mean effect sizes by welfare regime

\begin{tabular}{|c|c|c|c|c|c|c|}
\hline \multicolumn{7}{|c|}{ Effect of children aged 0-6 on maternal employment entry } \\
\hline & \multirow{2}{*}{ Number of studies $\mathrm{N}$} & \multicolumn{3}{|c|}{ Effect size } & \multicolumn{2}{|c|}{ Homogeneity test } \\
\hline & & mean & t-stat & $\mathrm{p}$-value & $\mathrm{Q}$ & p-value \\
\hline Total & 55 & -0.29 & -7.28 & 0.000 & 677.1 & 0.000 \\
\hline Conservative & 31 & -0.61 & -6.60 & 0.000 & 153.3 & 0.000 \\
\hline Familialistic & - & - & - & - & - & - \\
\hline Liberal & 19 & -0.09 & -2.80 & 0.005 & 182.9 & 0.000 \\
\hline Post-socialist & - & - & - & - & - & - \\
\hline Social-democratic & 5 & -0.40 & -1.48 & 0.140 & 60.8 & 0.000 \\
\hline Socialist & - & - & - & - & - & - \\
\hline \multicolumn{7}{|c|}{ Effect of female employment on childbearing } \\
\hline & \multirow{2}{*}{ Number of studies $\mathrm{N}$} & \multicolumn{3}{|c|}{ Effect size } & \multicolumn{2}{|c|}{ Homogeneity test } \\
\hline & & mean & t-stat & $\mathrm{p}$-value & $\mathrm{Q}$ & $p$-value \\
\hline Total & 90 & 0.00 & -0.13 & 0.901 & 115.9 & 0.000 \\
\hline Conservative & 18 & -0.27 & -1.94 & 0.053 & 25.7 & 0.085 \\
\hline Familialistic & 15 & -0.44 & -3.95 & 0.000 & 219.7 & 0.000 \\
\hline Liberal & 5 & -0.29 & -5.63 & 0.000 & 25.6 & 0.000 \\
\hline Post-socialist & 5 & 0.16 & 4.05 & 0.000 & 3.2 & 0.662 \\
\hline Social-democratic & 31 & -0.05 & -1.22 & 0.223 & 270.2 & 0.000 \\
\hline Socialist & 16 & 0.00 & -0.13 & 0.901 & 83.4 & 0.000 \\
\hline
\end{tabular}

NOTE: The table includes the random effect estimates.

Nevertheless, despite the disaggregation by welfare regimes, the Q-statistic shows that the effect sizes presented in Table 3 still contain a large amount of variation and cannot be treated as reliable estimates. As mentioned above, the variation may be a result of the methods applied, the data looked at, the sample restrictions made, the type of the transitions studied, and the reference categories or definitions of the child's age variable employed. In order to deal with this problem, we estimated meta-regressions. The results are presented in the next sub-section. 


\subsection{Multivariate analysis}

The most serious problem we encountered while estimating the parameters in meta-regression was the relatively low number of studies. We thus decided to include all variables that in our opinion may strongly contribute to the high variation in the effect size, e.g. the type of welfare regime, the cohort, the type of transition, the type of the reference category of the effect sizes, the definition of the child's age variable, the sample selection, the method applied, and the more important control variables employed in the original studies. It was unfortunately not possible to study in detail the effect of the applied research method or the type of the data used (retrospective, panel, administrative).

In order to evaluate the robustness of our estimates, we conducted a sensitivity analysis (Appendix 2). Namely, we reduced each sample randomly by $10 \%$ and estimated both models with the same covariates. The outcomes remained stable, demonstrating the reliability of our findings.

The meta-regression estimates are presented in Table 4. While interpreting the results of the meta-regression, we assume the direction of the correlation sign between women's employment and childbearing to be negative. This assumption is consistent with the results of our univariate metaanalyses and the results of the majority of the papers on the topic. Hence, the positive coefficients in the meta-regression are interpreted to constitute an increase in the effect size or in other words a reduction in the negative effect size. Similarly, negative coefficients are interpreted to represent a decline in the effect size, which means that the negative effect is intensified.

The results of the multivariate analysis are generally in line with the results of the univariate one as regards the variation of the studied effects among the institutional settings. The negative effect of children aged 0-6 on mothers' employment entry is definitely strongest in the conservative welfare regime and lowest in the social-democratic regime. The liberal institutional setting lies inbetween these two poles. The negative effect of women's work on childbearing is strongest in the familialistic, liberal, and conservative welfare regimes and lowest in the post-socialist ones. The socialist and social-democratic welfare regimes are characterised by the effect of females' employment on childbearing at an intermediate level.

As regards the variation in the effect sizes across cohorts the multivariate analysis show that the negative effect of women's work on fertility has decreased over time. Exactly the opposite is concluded on the effect of young children on women's employment entry.

As far as the research method is concerned, we did not have many options for selection of the covariates. Nearly all studies included in the analysis employed event-history techniques, applying continuous or discrete time models. In only one paper, which focused on the influence of young children on women's employment, did the authors estimate the fixed-effect OLS regressions on the annual data separately for the US and Switzerland. This was the only work among those studying the impact of young children on females' employment entry that controlled for unobserved heterogeneity. As regards the studies investigating the impact of women's work on fertility, the unobserved characteristics of the females were also rarely taken into account. The low number of studies controlling for unobserved heterogeneity made it impossible to test its impact on the studied effects. Therefore, as regards the method we only decided to include variables testing the influence of the continuous vs. discrete time models on the effect sizes into both meta-equations. Our results 
show that in both cases analysed, the models with continuous time tend to yield higher effect size estimates than models with discrete time. This finding is consistent with that of Zhang and $\mathrm{Yu}$ (1998, pp.1690), who show that if the event of interest is relatively frequent, the odds ratios tend to underestimate the relative risk if it is below one.

Table 4 Meta-regression estimates

\begin{tabular}{|c|c|c|c|}
\hline & & $\begin{array}{l}\text { Effect of children aged 0-6 } \\
\text { on maternal employment } \\
\text { entry }\end{array}$ & $\begin{array}{l}\text { Effect of female } \\
\text { employment on } \\
\text { childbearing }\end{array}$ \\
\hline \multirow[t]{11}{*}{ Welfare regime } & \multirow{2}{*}{ conservative } & $-1.06^{\star \star}$ & 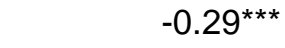 \\
\hline & & $(0.47)$ & $(0.07)$ \\
\hline & \multirow{2}{*}{ liberal } & $-0.79 *$ & $-0.35^{\star *}$ \\
\hline & & $(0.48)$ & $(0.16)$ \\
\hline & \multirow{2}{*}{ socialist } & 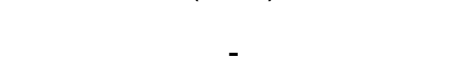 & -0.26 \\
\hline & & - & $(0.06)$ \\
\hline & \multirow{2}{*}{ post-socialist } & - & $0.30 * * *$ \\
\hline & & - & $(0.09)$ \\
\hline & \multirow{2}{*}{ familialistic } & & $-0.49 * * *$ \\
\hline & & - & $(0.06)$ \\
\hline & social-democratic & ref. & ref. \\
\hline \multirow{3}{*}{ Cohort } & \multirow{2}{*}{ birth cohort >= 1960} & $-0.57^{* \star *}$ & $0.17^{* \star *}$ \\
\hline & & $(0.17)$ & $(0.03)$ \\
\hline & birth cohort < 1960 & ref. & ref. \\
\hline \multirow[t]{3}{*}{ Method } & \multirow{2}{*}{ continuous time } & $0.65^{\star \star \star}$ & $0.14^{*}$ \\
\hline & & $(0.21)$ & $(0.10)$ \\
\hline & discrete time & ref. & ref. \\
\hline \multirow[t]{6}{*}{$\begin{array}{l}\text { Control } \\
\text { variables }\end{array}$} & \multirow{2}{*}{ partner } & 0.23 & $0.37^{\star \star \star}$ \\
\hline & & $(0.22)$ & $(0.04)$ \\
\hline & \multirow{2}{*}{ background } & $0.32^{*}$ & 0.02 \\
\hline & & $(0.17)$ & $(0.58)$ \\
\hline & \multirow{2}{*}{ job characteristic } & -0.25 & $0.30^{* * *}$ \\
\hline & & $(0.26)$ & $(0.04)$ \\
\hline \multirow{7}{*}{$\begin{array}{l}\text { Parity } \\
\text { Progression }\end{array}$} & \multirow{3}{*}{ parity one } & \multirow{3}{*}{-} & $0.24 * *$ \\
\hline & & & \\
\hline & & & $(0.11)$ \\
\hline & \multirow{2}{*}{ parity two } & \multirow{2}{*}{-} & -0.03 \\
\hline & & & $(0.11)$ \\
\hline & \multirow{2}{*}{ parity three } & \multirow{2}{*}{-} & -0.09 \\
\hline & & & $(0.10)$ \\
\hline \multicolumn{2}{|l|}{ No of studies } & 55 & 90 \\
\hline
\end{tabular}

NOTE: $* * *<0.01, * *<0.05, *<0.1$. Standard errors are reported in the parentheses. The results are standardized for the construction of the variable describing the effect of children on mothers' employment entry or the variable describing the effect of employment on childbearing, the type of the transition, the sample selected, and the inclusion of non-white populations (this regards mainly studies on the US). 
The remaining covariates in our meta-regressions regard the variables included by various researchers into the original models. Incorporating them into our analysis allows us to answer the question of how the inclusion of a particular variable affects the studied effect sizes. Our results show that controlling for partner characteristics (employment, occupation, wage, education), the social background of the respondent (e.g. parents' education, parents' occupation, parents' home ownership) and women's job characteristics ${ }^{\S}$ (wage, occupation, working hours, type of contract or employment sector) tends to influence the magnitude of the effect sizes.

Generally, taking into account the above mentioned characteristics reduces the negative impact of young children on mothers' employment entry or the impact of females' work on fertility. This finding is consistent with our expectations. It shows that the employment and childbearing decisions of a woman are determined by a set of external opportunities and constraints. A labour market status of the male partner means high income security for the female partner, which in financial terms allows her to withdraw temporarily from the labour market for the period of delivery and care. Therefore, by omitting the partner's characteristics the researcher overestimates the negative influence of women's employment on childbearing. Surprisingly, controlling for partner characteristics occurred to have no impact on the effects of young children on females' employment entry.

Analogous conclusions can be drawn on the role of the social background. Not only may it influence the attitudes of a woman and her partner towards the gender roles but also the economic environment in which the employment and childbearing decisions are taken. Therefore, including the social background of the respondent into the model absorbs part of the negative effect of young children on females' employment. It does not have, however, a significant impact on the effect of women's work on fertility.

The last set of control variables are the respondent's job characteristics. They define the level of woman's security at the workplace and her chances of promotion. Our results show that controlling for job characteristics significantly reduces the negative effect of women's work on childbearing but surprisingly does not have an impact on the effect of young children on mothers' employment entry.

Finally, the meta-model investigating the effect of women's employment on childbearing controls for the order of birth. The results show that the negative effect of females' work on childbearing is much lower in the case of first parity compared to a higher parity. This result confirms the assumption that the reconciliation of motherhood with work is a complex matter, inducing high opportunity costs, when there is more than one child at home.

\footnotetext{
$\S$ In the models studying transition to employment the job characteristics, if considered, refer to the job of a woman prior to the non-employment spell.
} 


\section{Discussion}

The examination of the interrelationship between women's employment and fertility at the microlevel has been a prominent issue in demographic and economic literature since a long time. There is no alternative to meta-analysis to bring light on this large number of empirical findings that allows a quantitative assessment of the effect of interest, standardised for the cross-study variation. In this paper, we have employed meta-analytic techniques to compare, synthesise, and interpret the large amount of worldwide studies on the topic. Two effects were analysed: the effect of women's work on fertility and the effect of young children on females' employment entry.

The first and main finding of our meta-study is a high variation in the analysed effects among the institutional settings. The conflict between employment and family is relatively low in the social-democratic and socialist welfare regime. In our opinion, this is related to the high institutional support to working mothers in both welfare regimes. Moreover, in the socialdemocratic welfare regime, the difficulties in combining employment and childrearing are reduced by relatively liberal attitudes towards working mothers, whereas in the socialist regime they were alleviated by strong job guarantees, low competition in the labour markets and socialist ideology forcing high fertility and high women's employment. Nevertheless, women's employment seems to depress fertility least in the post-socialist welfare regime. The univariate analysis even showed that woman's work is facilitated by childbearing. This finding seems to be striking since following the fall of the socialist regime the Eastern European countries experienced a severe fall in women's labour-force participation and fertility, accompanied to a large extent by a withdrawal of the state from institutional support of working mothers (e.g. Kotowska 1999; Stropnik 2003). Furthermore, studies by Muszyńska (2007, p. 93-96) and Lück and Hofäcker (2003) reveal that attitudes towards working mothers in the post-socialist countries are relatively traditional when compared to the rest of Europe. We believe, however, that the observed positive influence of women's employment on childbearing may be the result of a strong income effect. Rapidly rising aspirations of individuals in Eastern Europe in the course of economic transformation, state withdrawal from financial support for families, and relatively low wages compared to the old EU member states may be a source of strong economic necessities that restrain one-breadwinner-couples from family formation. Moreover, individuals may be less willing to bear children when their economic situation is uncertain. Women on temporary contracts, on the risk of losing a job, unemployed or married to men with unstable employment may be more reluctant to have children due to economic problems and the fear of jeopardizing chances to maintain or find employment in case of pregnancy and childbearing. Moreover, following Kreyenfeld (2004), the positive impact of employment on birth in the post-socialist countries may also be due to a highly internalised impairment of work and childbearing in the past.

In the remaining welfare regimes, the conflict between work and family is much stronger and its magnitude increases as we move from liberal to conservative and familialistic welfare regimes. These results are consistent with our expectations. The high labour market flexibility in the UK and the US allows mothers to enter employment fairly rapidly after a career break, which may compensate in part for the lack of public support for working parents. In contrast to the liberal welfare regime, the conservative and familialistic institutional settings are characterised by 
relatively rigid labour markets and more traditional attitudes towards working mothers, additionally to low institutional support for working parents.

Apart from the high regional variation in the studied effects, we found a significant change in their magnitude over time. Our results undoubtedly show a significant reduction in the negative impact of women's work on fertility. On the other hand, however, it turns out that the negative influence of young children on women's employment entry has even strengthened. In our opinion a complex interplay of several factors is responsible for this state of affairs. Changing attitudes towards working mothers and evolving family policies directed at work and family reconciliation in many of the developed countries in the recent decades have improved the conditions for childbearing for working women, albeit at very diverse rates. Hence, these cultural and institutional factors might have contributed to a decline in the negative impact of women's work on fertility. On the other hand, however, increasing competition in the labour markets and consequently rising requirements of employers as regards mobility and availability in the globalising world have diminished chances of employment (re-)entry for mothers who withdrew from the labour force for the period of delivery and care or delivered while being out of employment. The anticipated inability to find a job or return to work after birth may force women to postpone childbearing until establishing a relatively good position in the labour market. In this situation women who plan to have a child will self-select themselves into employment prior to childbearing. Such behaviour weakens the observed negative effect of employment on fertility, but in the conditions of increasing uncertainty in the labour markets it may lead to a continued postponement in childbearing and a further decline in fertility. Finally, apart from the developments described above, an increase in the negative impact of young children on women's employment entry might also result from a change in the characteristics of women participating in the labour force. Since in the past it was common for women to stay at home those who worked were very likely to be strongly work-oriented. For this group of women having children did not constitute a large obstacle to work. Nowadays, the majority of women participate at least for some time in paid employment and the highly workoriented constitute only a fraction of them.

Both the regional and time variation of the studied effects suggest that the correlation between women's employment and fertility is at least partly spurious, possibly caused by a simultaneous influence of common antecedents. This implies that regional and/or temporal variations in institutional factors (like childcare subsidies, taxation policies, and other forms of family support) structural factors (e.g. labour market rigidities or high uncertainty in the markets), and socio-cultural factors (such as attitudes toward working mothers and perception of the gender roles) have been important in determining the magnitude of the conflict between work and family. This finding is consistent with that of Rindfuss and Brewster (2000), Rindfuss et.al. (2003), Kögel (2004) and Engelhardt et.al. (2004) that country-specific effects mediate the correlation between fertility and women's work at the macro-level. At the same time, however, our study indicates that the change in the association between fertility and women's work is more ambiguous than it was found by the macro-level researchers. This points out at a large complexity in the dynamics of this relationship and calls for its deeper investigation that should involve a use of more advanced statistical tools able to tackle the selectivity and endogeneity problems. 
One of the most interesting results of our analysis regards the appropriateness of controlling for certain covariates while studying the interrelation between work and fertility. A failure to take the information on the job characteristics and social background of the woman as well as the labourmarket status of the partner into account may cause biases to the estimates, resulting in the overestimation of the negative effect of women's work on fertility or the negative effect of young children on mothers' employment entry. In particular, only recently have some studies underlined the importance of taking into consideration the role of the partner as the second actor of the reproductive process (e.g. Blossfeld et. al. 2001; Kreyenfeld 2005). We demonstrated the consistency of this approach.

\section{Acknowledgements}

This work has been prepared at the Max Planck Institute for Demographic Research during our stay as fellows in the European Doctoral School of Demography 2005/06, and then in the Laboratory on Contemporary European Fertility and Family Dynamics in the Winter Semester 2006/07. The library of the Max Planck Institute for Demographic Research is gratefully acknowledged for having provided us with the articles for this analysis. The paper profited remarkably from discussions with Gunnar Andersson, Gabriele Doblhammer, Irena E. Kotowska, Michaela Kreyenfeld, Gerda Neyer, Beata Nowok, and Silvana Salvini. This work has been presented at the "Interdisciplinary Workshop on Meta-Analysis" at the University of Cologne (Germany), 26-27 October 2006, whose participants provided us with very useful comments. We would also like to thank Susann Backer for the language editing.

\section{References}

Ahn, Namkee and Pedro Mira. 2002. A note on the changing relationship between fertility and female employment rates in developed countries, Journal of Population Economics 15(4): 667-682.

Amato, Paul R. and Bruce Keith.1991. Parental Divorce and Adult Well-Being: A Meta-Analysis, Journal of Marriage and Family 53(1): 43-58.

Apps, Patricia and Ray Rees. 2004. Fertility, Taxation and Family Policy, Scandinavian Journal of Economics, 106(4):745-763.

Becker, Gary S. 1993. A Treatise on the Family. Cambridge, Massachusetts: Harvard University Press.

Begg, Colin B. and Madhuchhanda Mazumdar. 1994. Operating Characteristics of a Rank Correlation Test for Publication Bias, Biometrics 50(4): 1088-1101. 
Berinde, Diana. 1999. Pathways to a Third Child in Sweden, European Journal of Population 15: 349-378.

Bernardi, Fabrizio. 2001. The Employment Behaviour of Married Women in Italy, in H-P. Blossfeld and S. Drobnič (eds.), Carrers of Couples in Contemporary Societies. Oxford: Oxford University Press, pp. 121-145.

Bernardi, Fabbrizio and Tiziana Nanio. 2005. Globalization and the transition to adulthood in Italy, in H-P. Blossfeld, Klizing, M.Mills, and K. Kurz (eds.), Globalization, Uncertainty and Youth in Society. London and New York: Routledge, pp. 349-374.

Blossfeld, Hans-Peter, Sonja Drobnič, and Götz Rohwer. 2001. Spouses' Employment Careers in (West) Germany, in H-P. Blossfeld and S. Drobnič (eds.), Carrers of Couples in Contemporary Societies. Oxford: Oxford University Press, pp. 53-76.

Brewster, Karin L. and Ronald R. Rindfuss 2000. Fertility and Women's Employment in Industralised Nations, Annual Review of Sociology 26:271-296.

Card, David and Alan B. Kruger. 1995. Time-Series Minimum-Wage Studies: A Meta-analysis, The American Economic Review 85(2): 238-243, Papers and Proceedings of the Hundredth and Seventh Annual Meeting of the American Economic Association.

Castles, Francis G. 2003. The world turned upside down: below replacement fertility, changing preferences and family-friendly public policy in 21 OECD Countries, Journal of European Social Policy 13(3): 209-229.

Corijn, M. (2001). Couples' Careers in Flanders. In H-P. Blossfeld \& S. Drobnič (eds.), Carrers of Couples in Contemporary Societies. Oxford: Oxford University Press, pp. 98-118.

Del Boca, Daniela, Rolf Aaberge, Ugo Colombino, John Ermisch, Marco Francescani, Silvia Pasqua, and Steinar Strøm. 2003. Labour market participation of women and fertility: The Effect of social policies, http://www.frdb.org/images/customer/paper_delboca.pdf.

Drobnič, Sonja. 2000. The Effects of Children on Married and Lone Mothers' Employment in the United States and (West) Germany, European Sociological Review 16(2):137-157.

Drobnič, Sonja, Hans-Peter Blossfeld, and Götz Rohwer. 1999. Dynamics of Women's Employment Patterns over the Family Life Course: A Comparison of the United States and Germany, Journal of Marriage and the Family 61(1):133-146.

Drobnič, Sonja and Immo Wittig. 1997. Part-Time Work in the United States of America, in H-P. Blossfeld and C.Hakim (eds.), Between Equalization and Marginalization. Women working Part-Time in Europe and the United States of America. Oxford: Oxford University Press, pp.289-314.

Engelhardt, Henriette, Tomas Kögel, and Alexia Prskawetz. 2004. Fertility and women's employment reconsidered: A macro-level time-series analysis for developed countries, 19602000, Population Studies 58(1):109-120.

Esping-Andersen, Gøsta. 1999. Social Foundations of Postindustrial Economies. Oxford: Oxford University Press.

Felmlee, Diane H. 1993. The Dynamic Interdependence of Women's Employment and Fertility, Social Science Research 22: 333-360.

Giannelli, Gianna Claudia. 1996. Women's transitions in the labour market: A competing risks analysis on German panel data, Journal of Population Economics 9(3): 287-300. 
Grunow, D., Hofmeister H., Buchholz S. (2006). Late 20th-Century Persistence and Decline of the Female Homemaker in Germany and the United States. International Sociology 21(1): 101131.

Grunow, D. \& Leth-Sørensen, S. (2006). Danish women's unemployment, job mobility and nonemployment, 1980s and 1990s: marked by globalization? In: H-P. Blossfeld \& H. Hofmeister (eds.), Globalisation, Uncertainty and women's Careers. An International Comparison. Cheltenham (UK) and Northampton (USA): Edward Elgar, pp. 142-170.

Hedges, Larry V. and Ingram Olkin. 1985. Statistical Methods for Meta-Analysis. Orlando: Academic Press.

Hofmeister, H. (2006). Women's employment transitions and mobility in the United States: 1968 to 1991, in: H-P. Blossfeld \& H. Hofmeister (eds.), Globalisation, Uncertainty and women's Careers. An International Comparison. Cheltenham (UK) and Northampton (USA): Edward Elgar, pp. 302-328.

Kögel, Tomas. 2004. Did the association between fertility and female employment within OECD countries really change its sign?, Journal of Population Economics 17(1): 45-65.

Kögel, Tomas. 2006. An explanation of the positive correlation between fertility and female employment across Western European countries, paper presented at the European Population Conference, Liverpool, the UK, June 2006.

Kotowska, Irena E. 1999. Drugie przejście demograficznego i jego uwarunkowania, in I.E. Kotowska (ed.), Przemiany demograficzne w Polsce w kontekście drugiego przejścia demograficznego. Warsaw: Warsaw School of Economics Publishing, pp. 11-33.

Kreyenfeld, Michaela. 2005. Economic uncertainty and fertility postponement - evidence from German panel data, MPIDR Working Paper 2005.

Kreyenfeld, Michaela. 2004. Fertility Decisions in the FRG and GDR: An Analysis with Data from the German Fertility and Family Survey, Demographic Research Special Collection 3: 275318.

Lesthaeghe, Ron. 1991. The Second Demographic Transition in Western Countries: An Interpretation, IPD Working Paper No 2, Vrije Universiteit, Brussel.

Lesthaeghe, Ron. 1992. The second demographic transition in Western Countries, in M.K. Oppenheim e A. Jensen (eds.), Gender and family change, Oxford: Clarendon Press, pp. 1762.

Leth-Sørensen, Søren and Götz Rohwer. 2001. Work Careers of Married Women in Denmark, in HP. Blossfeld and S. Drobnič (eds.), Carrers of Couples in Contemporary Societies. Oxford: Oxford University Press. pp. 261-279.

Lück, Detlev and Dirk Hofäcker. 2003. Rejection and Acceptance of the Male Breadwinner Model: Which Preferences do Women Have under Which Circumstances? Globalife Working Paper No 60, University of Bamberg.

Matysiak, Anna and Stephanie Steinmetz. 2006. Who follows whom? Female employment patterns in West Germany, East Germany and Poland, MZES Working Paper No 94, Mannheimer Zentrum fuer Europaeische Sozialforschung, Mannheim.

Muszyńska, M. (2007). Structural and cultural determinants of fertility in Europe. Warsaw: Warsaw School of Economics Publishing.

Rindfuss, Ronald R., Karen Benjamin Guzzo, and S. Philip Morgan. 2003. The Changing Institutional Context of Low Fertility, Population Research and Policy Review 22: 411-438. 
Róbert, P. \& Bukodi E. E. (2005), The effects of the globalization process on the transition to adulthood in Hungary. In H-P. Blossfeld, E. Klizing, M. Mills, \& K. Kurz (eds.), Globalization, Uncertainty and Youth in Society. London and New York: Routledge, pp. 176214.

Rosenthal, Robert. 1979. The "File Drawer Problem" and Tolerance for Null Results, Psycological Bulletin 86(3): 638-641.

Santow, Gigi and Michael Bracher. 2001. Deferment of the First Birth and Fluctuating Fertility in Sweden, European Journal of Population 17: 343-363.

Stanley, T.D. 2001. Wheat from Chaff: Meta-Analisis as Quantitative Literature Review, The Journal of Economic Perspetives 15(3): 131-150.

Stropnik, Nada. 2003. Impact of transition on family policy, in I.E. Kotowska and J. Jóźwiak (eds.), Population of Central and Eastern Europe - Challenges and Opportunities. Warsaw: Statistical Publishing Establishment.

Stuck, Andreas E., Jutta M. Walthert, Thorsten Nikolaus, Christophe J. Büla, Christoph Hohmann, and John C. Beck.1999. Risk factors for functional status decline in community-living elderly people: a systematic literature review, Social Science \& Medicine 48: 445-469.

Van De Kaa, Dirk J. 1987. Europe's second demographic transition, Population Bulletin 42(1), Population Reference Bureau, Washington, DC, USA.

Van de Kaa, Dirk J. 1988. The Second Demographic Transition Revisited: Theories and Expectations, paper presented at the conference on Population and European Society by the Commission of the European Economic Community and the European University Institute, Florence, 7-9 December.

Vemer, Elizabeth, Marilyn Colema, Lowrence H. Ganog, and Harris Cooper. 1989. Marital Satisfation in Remarriage: A Meta-Analysis, Journal of Marriage and Family 51(3): 713-725.

Wagner, Michael and Bernd Weiß. 2006. On the Variation of Divorce Risks in Europe: Findings from a Meta-Analysis of European Longitudinal Studies, European Sociological Review, Advanced Access published on August 18.

Waldorf, Brigitte and Pillsung Byun. 2005. Meta-analysis of the impact of age structure on fertility, Journal of Population Economics 18: 15-40.

Weichselbaumer, Doris and Rudolf Winter-Ebmer. 2005. A Meta-Analysis of the International Gender Gap, Journal of Economics Survey 19(3): 479-511.

Weller, Robert H. 1977. Wife's employment and cumulative family size in the United States, 1970 and 1960, Demography 14(1): 43-65.

Zhang, Jun and Kay F. Yu. 1998. What's the Relative Risk?, Journal of the American Medical Association, 280(19): 1690-1691. 


\section{APPENDIX 1: Papers used in the meta-analysis}

\section{Employment entry}

Bernardi, Fabrizio. 2001. The Employment Behaviour of Married Women in Italy, in H-P. Blossfeld and S. Drobnič (eds.), Carrers of Couples in Contemporary Societies. Oxford: Oxford University Press, pp. 121-145.

Buchholz, Sandra and Daniela Grunow. 2006. Women's employment in West Germany, in H-P. Blossfeld and H. Hofmeister (eds.), Globalisation, Uncertainty and women's Careers. An International Comparison. Cheltenham (UK) and Northampton (USA): Edward Elgar, pp. 6183.

Charles, Maria, Marlis Buchmann, Susan Halebsky, Jeanne M. Powers, and Marisa M. Smith. 2001. The Context of Women's Labour Market Careers. A Cross-National Study, Work and Occupations 28(3): 371-396.

De Graaf, Paul and Edwig Vermeulen. 1997. Female Labour-Market Participation in the Netherlands: Developments in the Relationship between Family Cycle and Employment, in HP. Blossfeld and C.Hakim (eds.), Between Equalization and Marginalization. Women working Part-Time in Europe and the United States of America. Oxford: Oxford University Press pp. 191-209.

Drobnič, Sonja and Ewa Frątczak. 2001. Employment Patterns of Married Women in Poland, in HP. Blossfeld and S. Drobnič (eds.), Carrers of Couples in Contemporary Societies. Oxford: Oxford University Press, pp. 281-306.

Drobnič, Sonja. 2000. The Effects of Children on Married and Lone Mothers' Employment in the United States and (West) Germany, European Sociological Review 16(2), 137-157.

Drobnič, Sonja, Hans-Peter Blossfeld, and Götz Rohwer. 1999. Dynamics of Women's Employment Patterns over the Family Life Course: A Comparison of the United States and Germany, Journal of Marriage and the Family 61(1):133-146.

Drobnič, Sonja and Immo Wittig. 1997. Part-Time Work in the United States of America, in H-P. Blossfeld and C.Hakim (eds.), Between Equalization and Marginalization. Women working Part-Time in Europe and the United States of America. Oxford: Oxford University Press, pp.289-314.

Giannelli, Gianna Claudia. 1996. Women's transitions in the labour market: A competing risks analysis on German panel data, Journal of Population Economics 9(3): 287-300.

Grunow, Daniela and Søren Leth-Sørensen. 2006. Danish women's unemployment, job mobility and non-employment, 1980s and 1990s: marked by globalization?, in: H-P. Blossfeld and H. Hofmeister (eds.), Globalisation, Uncertainty and women's Careers. An International Comparison. Cheltenham (UK) and Northampton (USA): Edward Elgar, pp. 142-170.

Felmlee, Diane H. 1993. The Dynamic Interdependence of Women's Employment and Fertility, Social Science Research 22: 333-360.

Grimm, Michael, Nöel Bonneuil. 2001. Labour Market Participation of French women over the Life cycle, 1935-1990, European Journal of Population 17(3):235-260.

Grunow, Daniela, Heather Hofmeister, and Sandra Buchholz. 2006. Late 20th century persistence and decline of the female homemaker in Germany and the United States, International Sociology 21(1): 101-132. 
Hendrickx, John, Wim Bernasco, and Paul M. de Graaf. 2001. Couple's Labour Market Participation in the Netherlands, in H-P. Blossfeld and S. Drobnič (eds.), Careers of Couples in Contemporary Societies, Oxford: Oxford University Press, pp. 77-98.

Hofmeister, Heater. 2006. Women's employment transitions and mobility in the United States: 1968 to 1991, in: H-P. Blossfeld and H. Hofmeister (eds.), Globalisation, Uncertainty and women's Careers. An International Comparison. Cheltenham (UK) and Northampton (USA): Edward Elgar, pp. 302-328.

Kalmijn, Matthijs and Ruud Luijkx. 2006. Changes in women's employment and occupational mobility in the Netherlands: 1995 to 2000, in: H-P. Blossfeld and H. Hofmeister (eds.), Globalisation, Uncertainty and women's Careers. An International Comparison. Cheltenham (UK) and Northampton (USA): Edward Elgar, pp. 84-114.

McCulloch, Andrew and Shirley Dex. 2001. Married Women's Employment Patterns in Britain, in H-P. Blossfeld and S. Drobnič (eds.), Carrers of Couples in Contemporary Societies, Oxford: Oxford University Press, pp. 175-200.

Ollikainen, Virve. 2006. Gender differences in Transitions from Unemployment: Micro Evidence from Finland, Labour 20(1): 159-198.

Shaw, Kathryn. 1994. The Persistsnce of Female Labour supply: Empirical Evidence and Implications, The Journal of Human Resources 29(2):348-378.

Leth-Sørensen, Søren and Götz Rohwer. 2001. Work Careers of Married Women in Denmark, in HP. Blossfeld and S. Drobnič (eds.), Carrers of Couples in Contemporary Societies. Oxford: Oxford University Press. pp. 261-279.

Taniguchi, Hiromi and Rachel A. Rosenfeld. 2002. Women's employment exit an reentry: differences among whites, blacks and Hispanics, Social Science Research 31: 432-471.

\section{Transition to chilbirth}

Aassve, Arnstein, Simon Burgess, Carol Propper, and Matt Dickson. 2006. Employment, family union and childbearing decisions in Great Britain, Journal of the Royal Statistical Society 169(4): 781-804.

Baizán, Pau, Arnstein Aassve, and Francesco Billari. 2003. Cohabitation, Marriage, and First birth: The Interrelationship of Family Formation Events in Spain, European Journal of Population 19: 147-169.

Baizán, Pau, Arnstein Aassve, and Francesco Billari. 2004. The interrelations between cohabitation, marriage and first birth in Germany and Sweden, Population and Environment 25(6): 531561.

Berinde, Diana. 1999. Pathways to a Third Child in Sweden, European Journal of Population 15: 349-378.

Berkowitz King, Rosalind. 2005. The case of the American women. Globalization and the transition to adulthood in an individualistic regime. in H-P. Blossfeld, Klizing, M.Mills, and K. Kurz (eds.), Globalization, Uncertainty and Youth in Society. London and New York: Routledge, pp. 305-326.

Bernardi, Fabbrizio and Tiziana Nanio. 2005. Globalization and the transition to adulthood in Italy, in H-P. Blossfeld, Klizing, M.Mills, and K. Kurz (eds.), Globalization, Uncertainty and Youth in Society. London and New York: Routledge, pp. 349-374. 
Bygren, Magnus, Ann-Zofie Duvander, and Mia Hultin. 2005. Elements of Uncertainty in life courses. Transitions to adulthood in Sweden, in H-P. Blossfeld, Klizing, M.Mills, and K. Kurz (eds.), Globalization, Uncertainty and Youth in Society. London and New York: Routledge, pp. 135-158.

Budig, J. Michelle. 2001. Are women's fertility and employment histories interdependent? An examintation of causal order using event history analysis, Social Science Research 32: 376401.

Corjin, Martine. 2001. Transition to adulthood in Flanders (Belgium), in M. Corjin and E. Klijzing (eds.), Transition to adulthood in Europe. Kluwer Academic Publisher

De La Rica, Sara and Mamaia Iza. 2005. Career Planning in Spain: Do Fixed Term Contract Delay Marriage and parenthood?, Review of the Economics of the Households 3: 49-73.

Francesconi, Marco and Katrin Golsch. 2005. The process of globalization and transition to adulthood, in H-P. Blossfeld, Klizing, M.Mills, and K. Kurz (eds.), Globalization, Uncertainty and Youth in Society. London and New York: Routledge, pp.249-276.

Garcia, Teresa Martin. 2006. Women's Education and Fertility in Spain. The Impact of Educational Attainment and the Educational Choice on First, Second and Third Births. Centro de Estudios Avanzados en Ciencias Sociales, 56, Madrid.

Kantorova, Vladimira. 2004. Family Life Transitions Of Young Women In A Changing Society: First Union Formation and Birth of First Child in The Czech Republic, 1970-1997. Doctoral Thesis.

Kravdal, Øystein. 1990. Who Has a Third Child in Contemporary Norway?: A Register-based Examination of Sociodemographic Determinants. Rapporter Fra Statistisk Sentralbyra.

Kravdal, Øystein. 1992. The Emergence of a Positive Relathion Between Education and Third Birth Rates in Norway with Supportive Evidence from the United States, Population Studies 46: 459-475.

Kravdal, Øystein. 1994. The importance of economic activity, economic potential and economic resources for the timing of first births in Norway, Population Studies 48: 249-267.

Kreyenfeld, Michaela. 2001. Employment and Fertility - East Germany in the 1990s. Doctoral Thesis.

Kreyenfeld, Michaela. 2004. Fertility Decisions in the FRG and GDR: An Analysis with Data from the German Fertility and Family Survey, Demographic Research Special Collection 3: 275318.

Kurz, Karin, Nikolei Steinhage, and Katrin Golsch. 2005. Case Study Germany. Global Competition, uncertainty and the transition to adulthood, in H-P. Blossfeld, Klizing, M.Mills, and K. Kurz (eds.), Globalization, Uncertainty and Youth in Society. London and New York: Routledge, pp.51-82.

Liefbroer, Aart C., Martine Corijn. 1999. Who, What, Where, and When? Specifying the Impact of Educational Attainment and Labour Force Partecipation on Family Formation, European Journal of Population 15: 45-75.

Liefbroer, Aart C. 2005. Transition from youth to adulthood in the Netherlands, in H-P. Blossfeld, Klizing, M.Mills, and K. Kurz (eds.), Globalization, Uncertainty and Youth in Society. London and New York: Routledge, pp. 83-104.

Meron, Monique, Isabelle Widmer, and Daniel Shapiro. 2002. Unemployment leads women to postpone the birth of their first child, Population 57(2): 301-330. 
Noguera, Carles Simó, Teresa Castro Martin, and Assunción Soro Bonmatì. 2005. The Spanish case. The effects of the globalization process on the transition to adulhood, in H-P. Blossfeld, E. Klizing, M. Mills, and K. Kurz (eds.), Globalization, Uncertainty and Youth in Society. London and New York: Routledge, pp. 375-402.

Olah, Livia Sz. 2003. Gendering fertility: Second births in Sweden and Hungary, Population Research and Policy Review 22: 171-200.

Olah, Livia Sz. and Ewa Frątczak E. 2004. Becoming a Mother in Hungary and Poland during State Socialism, Demographic Research Special Collection 3: 213-244.

Pinnelli, Antonella and Paola Di Giulio. 2003. Genere e determinanti della fecondità nei Paesi sviluppati, in A. Pinnelli, F. Racioppi, and R. Rettaroli (eds.), Genere e Demografia. Bologna: Il Mulino.

Ptak-Chmielewska, Aneta. 2005. Przebieg równoległych karier kobiet w Polsce w okresie poprzedzającym transformację systemową w świetle badań retrospektywnych z lat $1988 \mathrm{i}$ 1991. Wykorzystanie modeli parametrycznych i semiparametrycznych, Studia Demograficzne 1(147): 50-71.

Róbert, Péter and Erzsébet Bukodi E. (2005), The effects of the globalization process on the transition to adulthood in Hungary, in H-P. Blossfeld, E. Klizing, M. Mills, and K. Kurz (eds.), Globalization, Uncertainty and Youth in Society. London and New York: Routledge, pp. 176-214.

Santow, Gigi and Michael Bracher. 2001. Deferment of the First Birth and Fluctuating Fertility in Sweden, European Journal of Population 17: 343-363.

Vikat, Andreas. 2004. Women's Labor Force Attachment and Childbearing in Finland, Demographic Research, Special Collection 3: 175-212. 


\section{APPENDIX 2}

Table 5 - Sensitivity analysis: meta-regression estimates after random exclusion of $10 \%$ of the sample

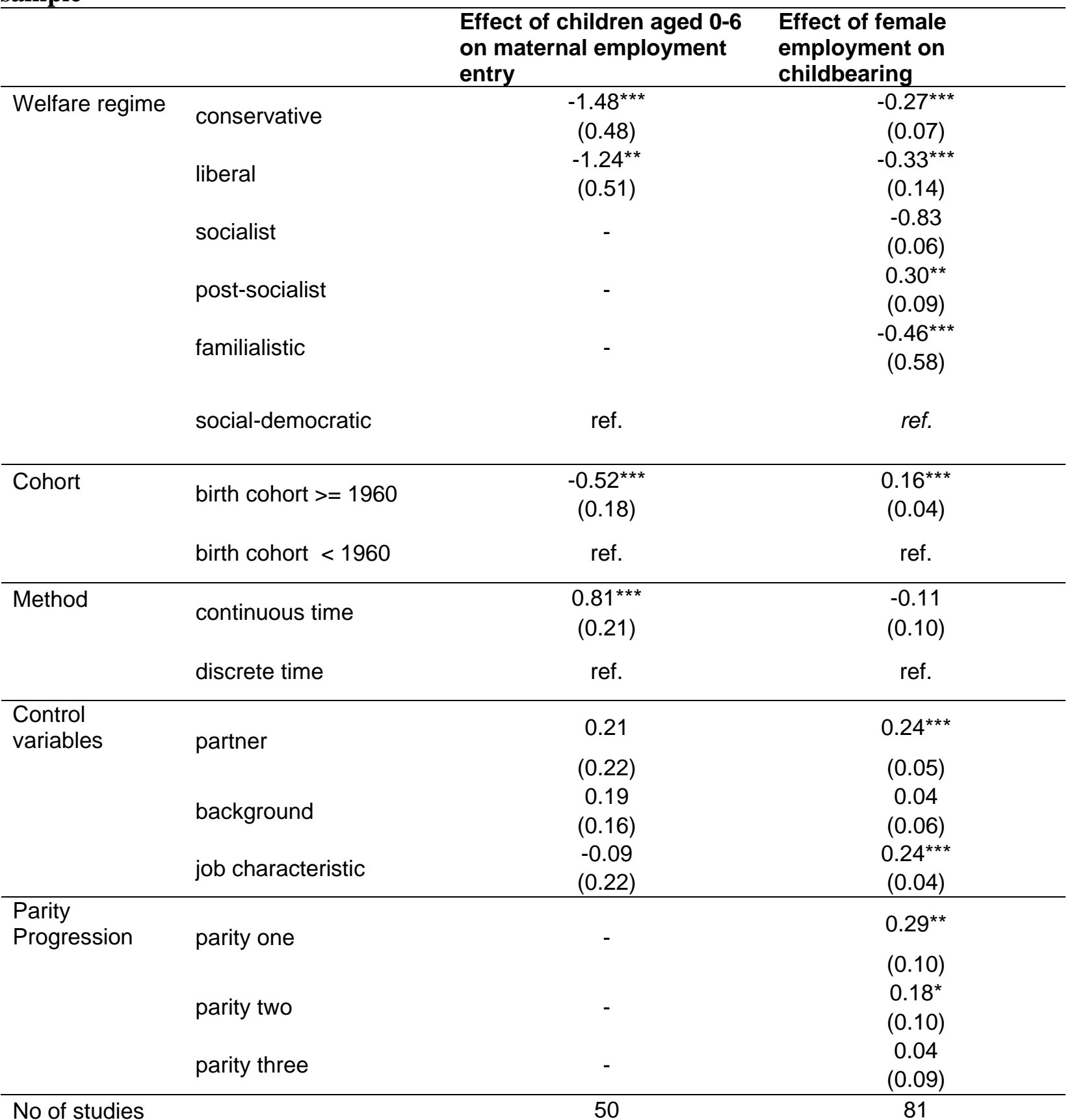

No of studies

NOTE: $* * *<0.01, * *<0.05, *<0.1$. In the parentheses we present standard errors. The results are standardized for the construction of the variable describing the effect of children on maternal employment entry and for the construction of the variable describing the effect of employment on childbearing, the type of the transition, the sample selected, and the inclusion of non-white populations (regards mainly studies on the US). 